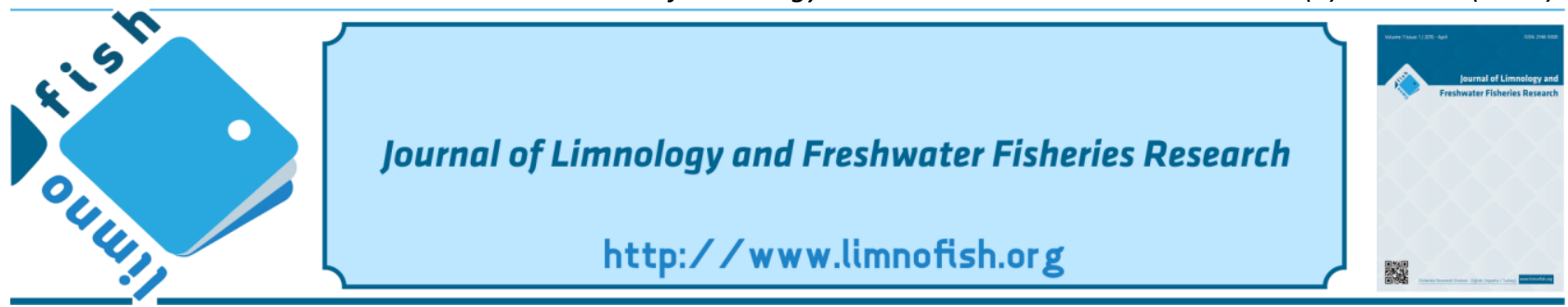

\title{
Method and Technical Characteristics of Traditional River Longline from Lower Sakarya River Fishery, Turkey
}

\author{
İsmail REİS (iD) Hasan CERIM * \\ Muğla Sıtk1 Koçman University, Faculty of Fisheries, Menteşe, Muğla, Turkey
}

\section{A B STR ACT}

In this study, a traditional longline set used in the lower Sakarya River was investigated. Technical characteristics and usage of the longline set were determined. Approximately 25-30\% of the fishermen in the lower Sakarya River use this method. Fishermen use the longline set with $30-40$ baited hooks by positioning them between the two banks of the river (30-60 m). Fishermen target relatively big individuals, especially, Silurus glanis. However, Esox lucius and some Cyprinidae species are also caught. The average daily catch is between 5$10 \mathrm{~kg}$ and captured $S$. glanis individuals are between $1-20 \mathrm{~kg}$. To ensure sustainability, catch per unit efforts of this traditional method, and spawning stock biomass should be monitored.

Keywords: River longline, Sakarya River, river fisheries, traditional fishery, freshwater

\section{ARTICLE INFO}

SHORT COMMUNICATION

$\begin{array}{ll}\text { Received } & : 21.10 .2019 \\ \text { Revised } & : 04.12 .2019 \\ \text { Accepted } & : 09.12 .2019 \\ \text { Published } & : 27.08 .2020\end{array}$

DOI:10.17216/LimnoFish.635248

* CORRESPONDING AUTHOR

hasancerim@gmail.com

Phone : +90554807 7945

\section{Aşağı Sakarya Nehri Balıkçılığından Alternatif Bir Geleneksel Nehir Paragat Yöntemi ve Teknik Özellikleri}

Öz: Bu çalışmada, Aşağı Sakarya Nehri’nde kullanılan geleneksel bir paraketa takımı incelenmiştir. Paraketa takımının teknik özellikleri ve kullanım şekli belirlenmiştir. Aşağı Sakarya Nehri'nde yaklaşık balıkçıların \%25-30'u bu yöntemi kullanmaktadır. Balıkçılar 30-40 adet yemlenmiş kancaya sahip paraketa takımını, nehrin iki kıyısı arasına (30-60 m) konumlandırarak kullanmaktadırlar. Balıkçılar özellikle Silurus glanis olmak üzere nispeten büyük balıkları hedeflemektedirler. Ancak Esox lucius ve bazı Cyprinidae türleri de yakalanmaktadır. Günlük ortalama toplam av 5-10 kg ve yakalanan S. glanis bireylerinin ağırlıkları 1$20 \mathrm{~kg}$ arasındadır. Sürdürülebilirliğin sağlanması için bu geleneksel yöntemin birim çabaya düşen av miktarı ve üreyen biyokütlenin izlenmesi gerekmektedir.

Anahtar kelimeler: Nehir paraketası, Sakarya Nehri, nehir balıkçılığı, geleneksel balıkçılık, tatlısu

How to Cite

Reis İ, Cerim H. 2020. Method and Technical Characteristics of Traditional River Longline from Lower Sakarya River Fishery, Turkey. LimnoFish. 6(2): 164-168. doi: 10.17216/LimnoFish.635248

\section{Introduction}

Fishing gears have been diversified according to technical characteristics of fishing gear, fishing ground, and targeted species (Hoşsucu 2005). Fishing lines are one of the most used fishing methods. This fishing method, which dates back to the ancient times (Kaykaç et al. 2003), is widely used in both commercial (Griffiths 2000) and amateur fishing today (Iwano and Öztürk 2012). The main reason for the widespread usage of this fishing gear that it can be used in all kinds of aquatic environments (Sitar et al. 2017; Pham et al. 2014), the cost is low (Bose et al. 2017) and construction and usage is simple. There are different types of fishing line as handlines and hand-operated pole-and-lines, mechanized lines, and pole-and-lines, set longlines, drifting longlines, longlines, vertical lines, trolling lines, hooks, and lines (CWP 2013).

Longline sets have a mainline and branchlines that are attached on mainline at certain intervals. Longline sets are known as demersal or pelagic fishing gears (FAO 2001). Longlines are used in the sea as well as in freshwater. In seas, different pelagic and demersal species are caught with longline sets like tuna (Francis et al. 2001), swordfish (Erdem and Akyol 2005), some Sparidae, Serranidae and Scorpaenidae species (Ulaş and Düzbastılar 2001), cod or flatfish (Hovgard and Lassen 2000). Bottom longlines are also used in freshwaters (von Brandt 1984). As an example, giant freshwater whipray 
(Urogymnus polylepis) which has minor commercial importance (Froese and Pauly 2019), is caught occasionally by longlines in riverine and estuarine areas (White et al. 2006). On the other hand, eellonglines are used in German freshwater fisheries (EIFAC 1970). However, other fishing methods, especially gill net fishery, are more common in freshwaters.

Fyke nets, trammel nets, and gill nets are used in the lower Sakarya River. Alburnus sp., Barbus barbus, Capoeta sp., Carrassius carrassius, Cyprinus carpio, Esox lucius, Lepomis gibbosus, Squalius cephalus, Mugil sp., Pseudorasbora parva, Rhodeus amarus, Scardinus erythrophytalmus, Tinca tinca, Chondrostoma nasus, Abramis brama, Blicca bjoerkna, Carrassius gibelio, Perca fluviatilis, Rutilus rutilus, Silurus glanis and Vimba vimba species are captured (Ateş et al. 2018; Aydın 2012).

There is no longline literature in the lower Sakarya River. In this study, it was aimed to determine the characteristics of traditional fishing gear and fishing method used in lower Sakarya River, Turkey.

\section{Materials and Methods}

This study was conducted between June 2017 and May 2018 in the $159.5 \mathrm{~km}$ section (Mekece in the south of Pamukova and Karasu Yenimahalle, where it flows into the Black Sea) of Sakarya River within the borders of Sakarya province (Figure 1). The study was conducted in two stages: face-to-face interviews with fishermen and fishing observations.

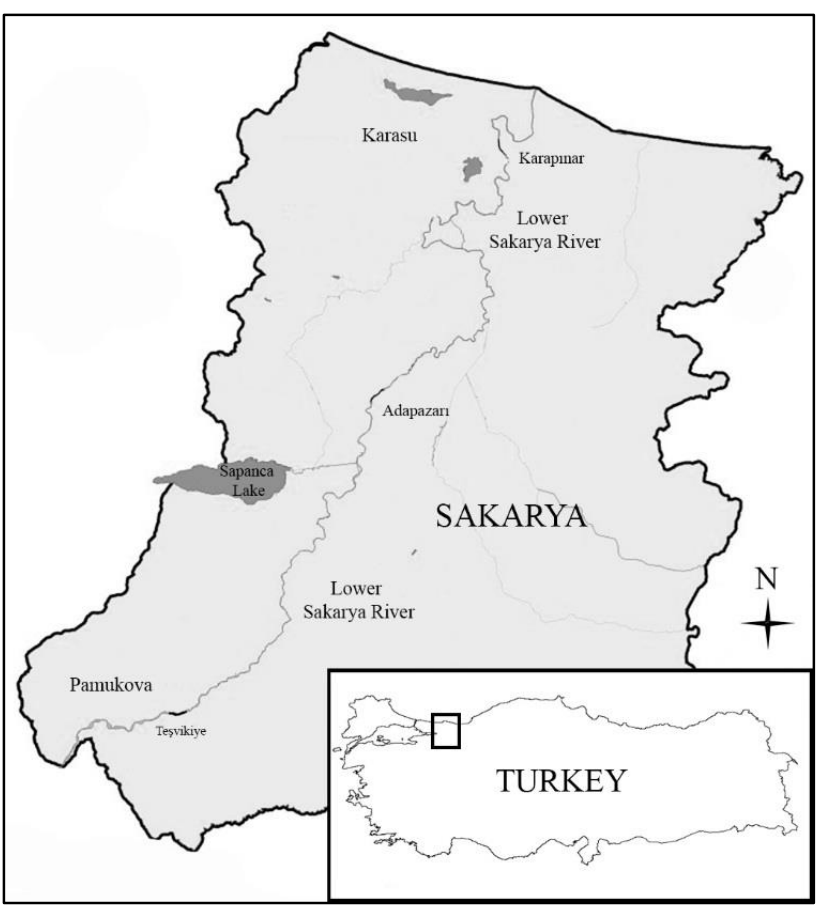

Figure 1. Study area

In the first stage, interviews were done with 17 fishermen. In these interviews, information was gathered about the technical characteristics of the fishing tackle (mainline and branchline number, length, material, hook type, and number, etc.), the baits used (species, size, live, fresh, etc.), fishing season, fishing area, caught species, targeted species, and the fishing problems.

In the second stage, it participated in three operations carried out by fishermen in the lower Sakarya River on different dates. In these operations, direct observations were made on bait supply methods, type, size, and usage of baits (live, fresh), the release time of fishing gear to the water, how the fishing operation is done, damages occurring in the fishing gear and catch composition.

Technical characteristics of the longline set were drawn according to the mode of FAO Catalogue of Small-scale Fishing Gear (Nédélec 1975).

\section{Results}

\section{Differences between other methods}

Even if the traditional longline set looks like trotline, it differs from trotline with weight usage. Various weights are used for sinker in trotline but any weight is not used in the traditional method. Therefore, the traditional method especially targets the surface fishes (i.e. no contact or connection with the bottom). Another similar example for longline, a method has been used for fish capture called "angling in the air", in China (von Brandt 1984). In this method, baited hooks stand above the water. Fish jump out of the water and then captured. This fish behavior is the main reason for the construction of this fishing gear. However, in our method, baits are near the water surface.

\section{Using method}

Firstly, the longline is set to between two opposing riverbanks (ranges of two sides vary between 30-60 meters) and stretched (Figure 2) then hooks are baited.

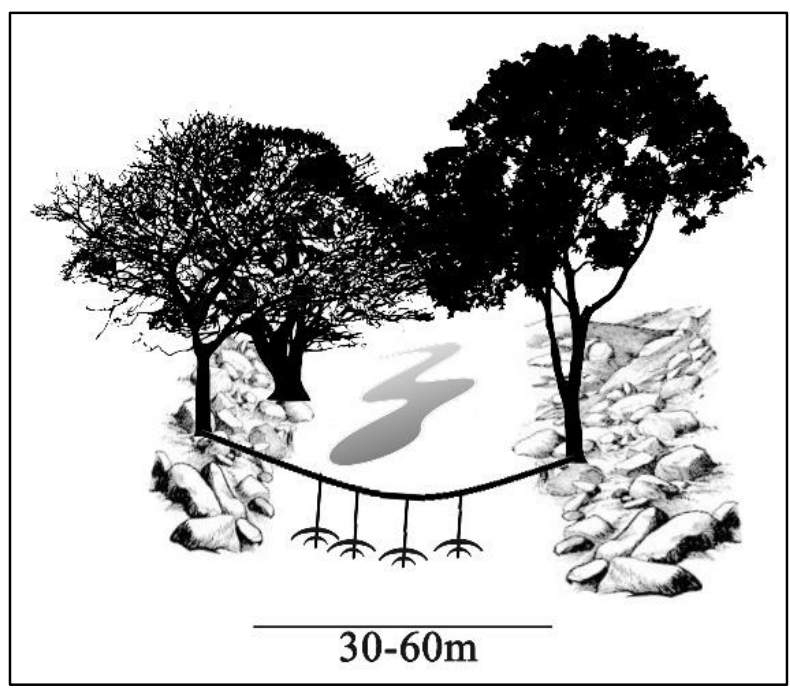

Figure 2. The setting of longline between river banks 
The longline set is released to water around sunset and is collected around sunrise. Due to catching large fishes, the longline set is always controlled every 1.5-2 hours till morning by the fisherman to prevent break-offs.

\section{Technical characteristics}

The Mainline is a 4-5 $\mathrm{mm}$ diameter multifilament PP (polypropylene) material. Branchlines are $60-80 \mathrm{~cm}$ long $\approx \approx 30-40$ number of branch lines) and are consisted of $2 \mathrm{~mm}$ monofilament PA (polyamide) or steel material. Branchlines have 1.5-2 meters range between each other. No swivel is used. Hooks are made of steel and hook sizes are changed between 2/0-6/0 no (Figure 3).

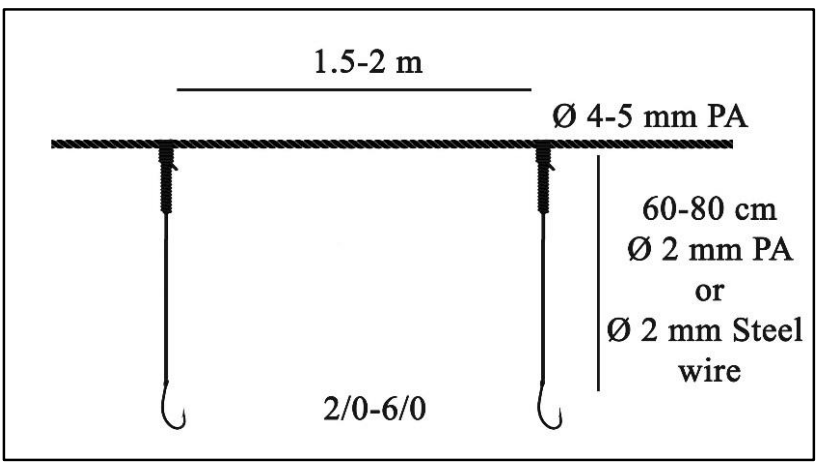

Figure 3. Technical characteristics of longline

\section{Baiting of hooks}

Baits are collected by fishermen from the surroundings. Hooks are baited with live frog, live fish, mole cricket, leeches, or fresh baits like chicken and turkey livers and meats after setting. Hooks are baited in different ways (Figure 4).

\section{Catch survey}

Approximately, 300 fishermen exist on the lower Sakarya River region and about $25-30 \%$ of them use this longline method. The most captured species are $S$. glanis (European catfish) and followed by $E$. lucius (Northern pike). Some Cyprinidae species are also caught, rarely. However, the targeted species is $S$. glanis. According to fishermen, the most productive months are between August and December. Approximately, $25-30 \%$ of fishermen use this method in the mentioned fishing season. Captured $S$. glanis individuals are between 1-20 kg ( $\approx 60-180 \mathrm{~cm})$. On the other hand, total daily catch is between 5-10 $\mathrm{kg}$.

\section{Environmental problems}

Trashes are one of the main problem of the lower Sakarya River fisheries. Trashes, especially plastic bags and logs, which swim on the surface of the river, damage to longline sets (break-offs of branchlines or main line). This situation affects catch efficiency and causes time and economic loss.

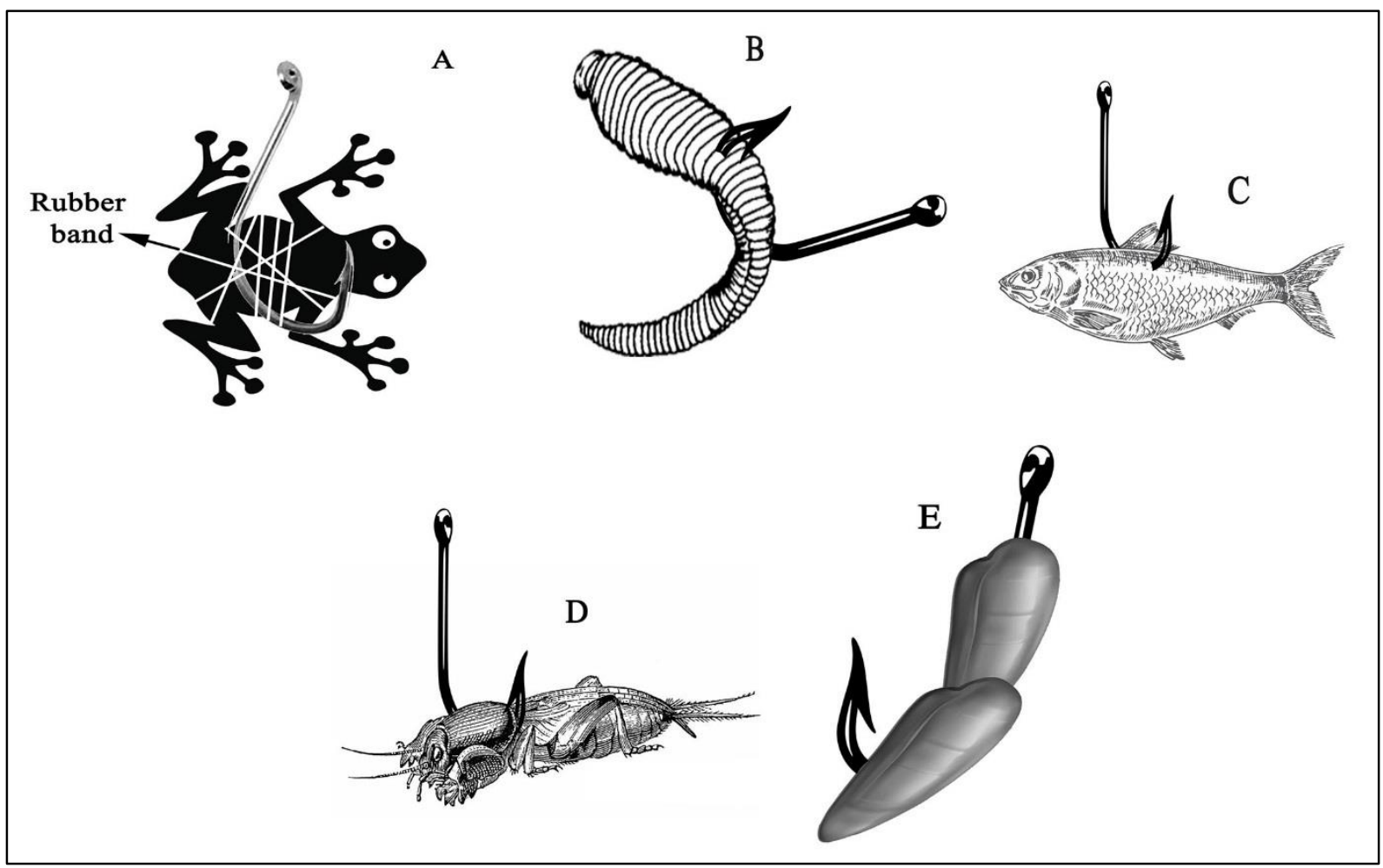

Figure 4. Different methods of baiting hook with various baits; A; Live frog, B; Leech, C; Live fish, D; Mole cricket, E; Liver of chicken or turkey 


\section{Discussion}

In Turkish fishery, longline sets are used widely in the small-scale fishery and there are some regulations in the meaning of sustainable fishery. Some rules are existing on commercial and amateur longline freshwater fishery like "using of living fish in pike-perch (Sander lucioperca L., 1758) and perch (P. fluviatilis L., 1758) fishery is forbidden" and "longline is forbidden in the amateur fishery" (GDFA 2016a, 2016b).

S. glanis and E. lucius are known as commercial species (Froese and Pauly 2019). The European catfish, S. glanis, has rapid growth and large bodyweight (Brzuska and Adamek 1999). Males and females become mature at $78.82 \mathrm{~cm}$ (3 years) and $87.05 \mathrm{~cm}$ (4 years), respectively (Alp et al. 2004). In fishery regulation, the minimum landing size of $S$. glanis is $90 \mathrm{~cm}$ (GDFA 2016a). Furthermore, there are season closures on this species. On the other hand, E. lucius becomes mature at $19.7 \mathrm{~cm}$ in total length (Balık et al., 2006) and has a $40 \mathrm{~cm}$ minimum landing size (GDFA 2016a). Season closures and fishing gear prohibition regulations also exist for this species. Minimum landing size regulations may support its stocks in the meaning of stock recruitment. Moreover, in this method, capturing of large individuals indicates that this gear is selective.

In different parts of the world, some researchers, Vejrik et al. (2017a) and Vejrik et al. (2017b) mentioned that they captured S. glanis and E. lucius individuals by longlines (with buoy and sinkers and no connection with landside). Also, Boulêtreau et al. (2016) did fishing trials on behavior of this species with longline but they did not give clear information about using of this fishing gear.

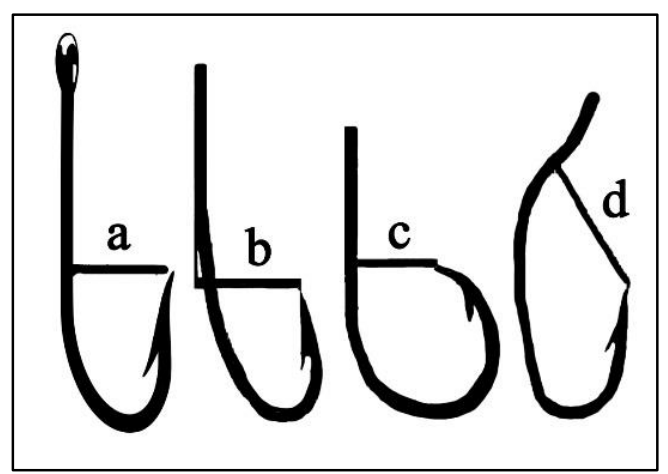

Figure 5. Allowed hook sizes; a, b, c and d ranges must not be lower than $7.2 \mathrm{~mm}$ (GDFA 2016a)

In the meaning of technical regulation of the longline, according to fishery rules, fishermen mustn't use the hooks that have a gap below $7.2 \mathrm{~mm}$ (Figure 5). This rule could be an effective regulation to conserve smaller length classes.

Fishery regulations seem sufficient. Small individuals are not captured and the breeding chance at least once is given to small individuals. Therefore, spawning stocks should be monitored not to make an overfishing pressure on targeted species' and fishermen should be educated in the direction of stock sustainability.

\section{Acknowledgements}

We would like to thank to local fishermen for technical information.

\section{References}

Alp A, Kara C, Büyükçapar HM. 2004. Reproductive biology in a native European catfish, Silurus glanis L., 1758, population in Menzelet Reservoir. Turk J Vet Anim Sci. 28(3):613622.

Ateş C, Reis İ, Cerim H, Çelik M. 2018. Sakarya Nehri'ndeki Balıkçılığının Belirlenmesi. Muğla: Muğla Sttk1 Koçman Üniversitesi. Proje No.:BAP17/073. [In Turkish.]

Aydın E. 2012. Sakarya Nehri'nde kullanılan fanyalı uzatma ağlarında seçiciliğin belirlenmesi [Master's Thesis]. İstanbul University. $75 \mathrm{p}$.

Balık I, Çubuk H, Özkök R, Uysal R. 2006. Reproduction properties of pike (Esox lucius L., 1758) population in Lake Karamik (Afyonkarahisar/Turkey). Turk J Zool. 30:27-34.

Bose AK, Ridhi, Gupta S, Suresh VR, Das AK. 2017. Indigenous fishing (Char Kanta): A traditional fisheries in River Tawa, Madhya Pradesh, India. International Journal of Fisheries and Aquatic Studies. 5(3):265-268.

Boulêtreau S, Verdeyroux P, Lorthiois E, Azémar F, Compin A, Santoul F. 2016. Do You Eat or Not? Predation Behaviour of European Catfish (Silurus glanis) Toward Live Bait on a Hook. The Open Fish Science Journal. 9:8-14. doi: 10.2174/1874401X01609010008

Brzuska E, Adamek J. 1999. Artificial spawning of European catfish, Silurus glanis L.: stimulation of ovulation using LHRH-a, Ovaprim and carp pituitary extract. Aquac Res. 30(1):59-64. doi: 10.1046/j.1365-2109.1999.00301.x

CWP 2013. Coordinating Working Party on Fishery Statistics. International Standard Statistical Classification of Fishing Gear (ISSCFG Rev. 1, 2013); [cited 2019 Aug 28]. Available from http://www.fao.org/3/a-bt987e.pdf

EIFAC (1970). European Inland Fisheries Advisory Commission. Consultation on Eel Fishing Gear and Techniques; [cited 2019 Sep 10]. Available from http://www.fao.org/3/c2876b/C2876B00.htm

Erdem M, Akyol O. 2005. A preliminary study on longlining of swordfish (Xiphias gladius Linnaeus, 1758) in Fethiye Region (Mediterranean). Ege Journal of Fisheries and Aquatic Sciences. 22(1):201-204. [In Turkish.]

FAO 2001. Food and Agriculture Organization of the United Nations. Fishing Gear types. Set longlines. Technology Fact Sheets; [cited 2019 Sep 13]. Available from http://www.fao.org/fishery/ 
Francis MP, Griggs LH, Baird SJ. 2001. Pelagic shark bycatch in the New Zealand tuna longline fishery. Mar Freshwater Res. 52(2):165-178. doi: 10.1071/MF00086

Froese R, Pauly D. 2019. FishBase. World Wide Web electronic publication; [cited 2019 Sep 20]. Available from www.fishbase.org

GDFA 2016a. General Directorate of Fisheries and Aquaculture. 4/1 Numaralı Ticari Amaçlı Su Ürünleri Avcılığının Düzenlenmesi Hakkında Tebliğg; [cited 2019 Sep 20]. Available from http://www.mevzuat.gov.tr/Metin.Aspx?MevzuatKod $=9.5 .22750 \&$ MevzuatIliski $=0 \&$ sourceXmlSearch $=$ tic ari\%20amaçli

GDFA 2016b. General Directorate of Fisheries and Aquaculture. 4/2 Numaralı Ticari Amaçlı Su Ürünleri Avcılığının Düzenlenmesi Hakkında Tebliğ; [cited 2019 Sep 20]. Available from http://www.mevzuat.gov.tr/Metin.Aspx?MevzuatKod $=9.5 .22751 \&$ MevzuatIliski $=0 \&$ sourceXmlSearch $=\mathrm{m}$ atör\%20amaçl1

Griffiths MH. 2000. Long-term trends in catch and effort of commercial linefish off South Africa's Cape Province: snapshots of the 20th century. S Afr J Marine Sci. 22(1):81-110. doi: 10.2989/025776100784125663

Hoşsucu H. 2005. Balıkçılık-I. İzmir: Ege Üniversitesi Su Ürünleri Fakültesi Yayınları 247 p. [in Turkish]

Hovgård H, Lassen H. 2000. Manual on estimation of selectivity for gillnet and longline gears in abundance surveys. Rome: FAO. Report No.: 397.

Iwano N, Öztürk AA. 2012. Fishing at the Galata Bridge, İstanbul, in 2011-2012. Journal of the Black Sea / Mediterranean Environment. 18(2):223-237.

Kaykaç MH, Ulaş A, Metin C, Tosunoğlu Z. 2003. Olta balıkçılığında düz ve çapraz iğnelerin av etkinliği üzerine bir araştırma. Ege Üniversitesi Su Ürünleri Dergisi. 20(1-2): 227-231
Nédélec C. 1975. FAO Catalogue of Small-Scale Fishing Gear. England: FAO by Fishing News (Books) Ltd. $191 \mathrm{p}$.

Pham CK, Diogo H, Menezes G, Porteiro F, BragaHenriques A, Vandeperre F, Morato T. 2014. Deepwater longline fishing has reduced impact on Vulnerable Marine Ecosystems. Sci Rep-UK. 4:4837. doi: 10.1038/srep04837

Sitar SP, Brenden TO, He JX, Johnson JE. 2017. Recreational Postrelease Mortality of Lake Trout in Lakes Superior and Huron. N Am J Fish Manage. 37(4):789-808. doi: 10.1080/02755947.2017.1327903

Ulaş A, Düzbastılar FO. 2001. Farklı Paragat Takımlarının Av Verimlerinin Karşılaştırılması. Ege Journal of Fisheries and Aquatic Sciences. 18(1-2):175-186. [In Turkish.]

Vejřík L, Vejříková I, Kočvara L, Sajdlová Z, Hoang TSC, Šmejkal M, Peterka J, Čech M. 2017a. ThirtyYear-Old Paradigm about Unpalatable Perch Egg Strands Disclaimed by the Freshwater Top-Predator, the European Catfish (Silurus glanis). Plos One. 12(1):e0169000. doi: 10.1371/journal.pone.0169000

Vejř́k L, Vejříková I, Blabolil P, Eloranta AP, Kočvara L, Peterka J, Sajdlová Z, Hoang The SC, Šmejkal M, Kiljunen M, Čech M. 2017b. European catfish (Silurus glanis) as a freshwater apex predator drives ecosystem via its diet adaptability. Sci Rep-UK. 7(1): 15970 . doi:10.1038/s41598-017-16169-9

Von Brandt A. 1984. Fish Catching Methods of the World. Farnham, Surrey: Fishing News Books Ltd. 432 p.

White WT, Last PR, Stevens JD, Yearsley GK, Fahmi, Dharmadi. 2006. Economically important s harks and rays of Indonesia. Canberra, Australia: Australian Centre for International Agricultural Research 338 p. 